\title{
Menace of Spiralling Whitefly, Aleurodicus dispersus Russell on the Agrarian Community
}

\author{
P. P. Pradhan ${ }^{1 *}$ and Abhilasa Kousik Borthakur ${ }^{2}$ \\ ${ }^{1}$ Department of Entomology, Assam Agricultural University, Jorhat, India \\ ${ }^{2}$ Krishi Vigyan Kendra, Assam Agricultural University, Darrang, India \\ *Corresponding author
}

\begin{abstract}
A B S T R A C T
\section{Keywords}

Spiralling whitefly, Aleurodicus disperses,

Polyphagous,

Ecology,

Parasitoids,

Predators

Article Info

Accepted:

18 November 2020

Available Online:

10 December 2020

Spiralling whitefly, Aleurodicus dispersus Russell, a polyphagous pest native to the Caribbean region and Central America has turned out to be cosmopolitan as well creating havoc to the farming community. The peculiar egg-laying pattern of this pest has given its name spiralling whitefly. The insect has four nymphal stages and has a pupal period of 2-3 days, thereby the total developmental period is of 18 to 23 days. It has been found that high temperature and high relative humidity during summer has a positive impact on pest incidence. As their body is covered with a heavy waxy material, management of this pest is quite a task. Since A. dispersus is an exotic pest in most of the countries, hence classical biological control through the introduction of natural enemies from the area of origin of the pest is considered as a sustainable management option. The natural enemies chiefly the parasitoids Encarsia guadeloupae Viggiani and Encarsia haitiensis Dozier has turned out to be a promising tool in suppressing the menace of spiralling whitefly.
\end{abstract}

\section{Introduction}

The spiralling whitefly, Aleurodicus dispersus Russell causes various threats to several agricultural and horticultural crops both within the glasshouse and field conditions in India. Aleurodicus dispersus Russell (Aleyrodidae) is an exceptionally polyphagous pest and belong to the Caribbean region and Central America (Russell, 1965), where it is known from a wide range of host plants, but not regarded as a pest (Waterhouse and Norris, 1989). Worldwide it is commonly known as 'spiralling whitefly' because it lays eggs in a particular spiral pattern (Kumashiro et al., 1983). It was introduced and assumed pest status in the Canary Islands in 1962 and Hawaii in 1978 (Paulson and Kumashiro, 1985), in American Samoa and Guam in 1981 (Firman, 1982) and then in most of the Pacific islands (Waterhouse and Norris, 1989).

The whitefly later spread westwards into several regions including Africa (Akinlosotu et al., 1993; M'Boob and van Oers, 1994; Neuenschwander, 1994), Asia (Anon., 1987; 
Wijesekera and Kudagamage, 1990; Kajita et al., 1991; Wen et al., 1994; Palaniswami et al., 1995) and Australia (Carver and Reid, 1996; Lambkin, 1998).

In South Asia, it is presently found in Bangladesh (Scanlan, 1995), Sri Lanka (Wijesekera and Kudagamage, 1990), the Maldives (Martin, 1990) and India (Palaniswami et al., 1995). In India, it was first recorded in 1993 at Thiruvananthapuram, Kerala on tapioca (Palaniswami et al., 1995) and later it was observed in Tamil Nadu (David and Regu, 1995; Sivaprakasam and Chandramohan, 1997), Karnataka (Mani and Krishnamoorthy, 1996), Andhra Pradesh (Reddy and Chandarkar, 1999), Maharashtra (Sathe, 1999), Lakshadweep islands (Ramani, 2000) and of late Orissa and North East Region. There is no concrete evidence regarding its mode of entry into India or the country from which it was introduced, but it probably came from Sri Lanka (Ranjith et al., 1996) or the Maldives (Muniappan, 1996). Spiralling whitefly was found in all the districts except Nilgiris in Tamil Nadu. The intensity of spiralling whitefly was more in Central and Southern Tamil Nadu (Geetha, 2000), while it was found in all the districts of Karnataka (Anon., 2001).

Nymphs and adults suck the sap from the leaves causing damage to several crops particularly cassava, chillies, mulberry, guava, banana, papaya, groundnut etc. in peninsular India (Mani and Krishnamoorthy, 1999a).

It is difficult to kill pest with conventional insecticides as they are covered with heavy waxy flocculent materials. But the natural enemies chiefly the parasitoids Encarsia guadeloupae Viggiani and Encarsia haitiensis Dozier proved to be highly useful in suppressing the spiralling whitefly in Pacific Islands, African and Asian countries (Mani and Krishnamoorthy, 2002) (Table 1-4).

\section{Biology}

The common name of $A$. dispersus, the spiralling whitefly, is derived from this characteristic egg-laying pattern, although other species of aleurodicine whitefly also lay eggs in spiral patterns (Martin, 1990). Female whitefly lays yellowish-white eggs, which hatch in 7 days (Ragumoorthy and Kempraj, 1996) and 4-6 days (Palaniswami et al., 1995) and 5-8 days (Geetha, 2000). Fecundity ranges from 51.8 to $64.06 \mathrm{eggs} /$ female (Mallapanavar, 2000). The eggs are laid singly at right angles to the leaf veins on spiral deposits of wax (Ramani and Bhumannavar, 2001). There are four nymphal instars, which are greenish, white and oval. The four nymphal instars pass through 2.156.50, 2.7-5.00, 2.9-5.96 and 6.5-8.1 days, respectively (Geetha, 2000). Fourth instar nymphs are covered with heavy wax material. The total nymphal period normally lasts for 12 to 14 days and the pupal period lasts for 2 to 3 days (Palaniswami et al., 1995). Thus, the development from egg to adult takes 18 to 23 days (Palaniswami et al., 1995) and 22.529.66 days (Geetha, 2000). Adults are larger with dark reddish-brown eyes and fore wings with characteristic dark spots. Adults live for about 2 weeks and are particularly active during morning hours. All the stages of whitefly can produce extra-cuticular waxes that cover the body (Ramani and Bhumannavar, 2001).

\section{Ecology}

The infestation of whiteflies is related to weather conditions (Mani, 2010). Heavy sporadic rains and cool temperatures result in a temporary reduction in A. dispersus population. However, dry conditions following rainfall between November and April, when both temperature and R.H. are high, favours pest outbreak (Palaniswami et al., 1995). According to Ranjith et al., (1996), the whitefly had increased in number 
drastically in summer and decreased after the pre-monsoon showers in Kerala. The pest incidence on mulberry was high during AprilJune in and around Bangalore (Narayanaswamy and Ramegowda, 1999). A. dispersus exhibited maximum infestation (19.44 PPI) in April (summer), lowest in September (0.79 PPI) and moderate in November (2.58 PPI)) on mulberry. The mulberry was free from this pest from August to October, which coincided with Kharif rains (Jagadish et al., 2003; Hemalatha and Shree, 2008). In Karnataka, the population of spiralling whitefly was found to be high during March-June and the density of the whitefly was positively correlated with maximum temperature and negatively correlated with relative humidity on guava (Mani and Krishamoorthy, 2000; Mallapanavar, 2000). Gopi et al., (2001a) found the incidence of spiralling whitefly to be higher during November-February in Coimbatore. A similar trend was observed around Pune and Hyderabad (Mani et al., 2000b). The nymphal population was low in June-July and reached a peak in November at Shimoga (Aiswariya et al., 2007b).

\section{Host range}

Being polyphagous, $A$. dispersus is known to attack about 500 plants in different countries (Mware et al., 2010) and 280 in India alone (Ramani et al., 2002; Mani, 2010). Douressamy et al., (1997) and Rajadurai and Thiagarajan (2003) have recorded the incidence on 38 genera of plants belonging to 27 families and above 100 species. $A$. dispersus was recorded on the plant species numbering 25 (David and Regu, 1995), 70 (Prathapan, 1996) and 22 (Ranjith et al., 1996) and 45 (Mani and Krishnamoorthy, 1999a), 27 (Gajendra Babu and David, 1999), 53 (Mariam et al., 2000), 27 (Ramani, 2000), 128 (Geetha and Swamiappan, 2001a), 94 (Muralikrishna, 1999), 102 (Mallapanavar,
2000) and 68 (Srinivasa, 2000) and 99 (Aiswariya et al., 2007a). The major host plants of economic concern in India are banana, guava, avocado, papaya, coconut, cucurbits, dahlia, gerbera, gladiolus, tomato, mulberry, tapioca and bell pepper, in addition to several species of shade trees in the urban environment. The families Fabaceae, Asteraceae, Malvaceae, Myrtaceae, Euphorbiaceae and Moraceae seem to contain the most species of host plants (Srinivasa, 2000; Geetha and Swamiappan, 2001a).

\section{Damage and loss}

Nymphs and adults congregate generally on the lower surface, but sometimes on the upper surface of leaves of the host plants, stem (cassia) and fruits (papaya) and suck the sap. Wen et al., (1995) reported a loss in fruit yield of $80 \%$ in guava attacked by the pest for four months consecutively in Taiwan, but estimates of yield loss due to this pest are not available in India. Ranjith et al., (1996) observed severe damage to many crops in Kerala and Geetha et al., (1998) observed severe incidence in a groundnut crop in Tamil Nadu. Heavy incidence of the whitefly caused yield reduction to an extent of $53.10 \%$ in tapioca (Geetha, 2000). Injury caused by heavy infestations was usually insufficient to kill the plants (Nambiar, 1997). Adverse impacts, such as longer larval duration, decreased food conversion and utilization and reduction in economic parameters of the cocoon, were noticed when the whiteflyinfested mulberry leaves were fed to the silkworm, Bombyx mori (L.) (Lepidoptera, Bombycidae), due to reduced nutrition levels in affected leaves (Mariam, 1999; Ahamed et al., 1999; Narayanaswamy et al., 1999). Severe infestation of spiralling whitefly reduces the quality of banana leaves commonly used to serve the food in all the functions in South India (Mani et al., 2003). In Kerala, chillies were found to be damaged 
by the spiralling whitefly (Beevi and Lyla, 2001). Heavy incidence of spiralling whitefly was observed on coconut during March-May 2000 in Madurai (Razak, 2002) and attack by these pest causes unseasonal leaf fall and consequent yield reduction in rubber (Ranjith et al., 1996).

Adults and nymphs of the whitefly cause damage by direct feeding on plant sap and when present in very large numbers can cause leaf fall, but even heavy infestations are insufficient to kill the plants. The copious white, waxy, flocculent material secreted by all the stages of the pest is readily spread by wind, creating a nuisance. Honeydew excreted by the nymphs encourages the growth of sooty mould on leaf surfaces, reducing the photosynthetic capacity of the plant (Kumashiro et al., 1983). The sticky honeydew carried by the wind on the flocculant wax adheres to windows and cars and causes considerable annoyances. Complaints were received for allergies and dermatitis.

\section{Management}

Management of whitefly is indeed a difficult task owing to the number of wild-grown host plants that support the build-up of the pest. Populations of this insect thrive in warm, dry weather.

Table.1 Common host plants of $A$. dispersus in India

\begin{tabular}{|c|c|c|}
\hline Botanical name & Common name & Family \\
\hline Abelmoschus esculentus & Lady's finger & Malvaceae \\
\hline Capsicum annum & Capsicum/Bell pepper & Solanaceae \\
\hline Coccinia indica & Coccinia & Cucurbitaceae \\
\hline Cucurbita maxima & Winter squash & Cucurbitaceae \\
\hline Ipomoea batata & Sweet potato & Convolvulaceae \\
\hline Solanum lycopersicum & Tomato & Solanaceae \\
\hline Manihot esculenta & Tapioca & Euphorbiaceae \\
\hline Moringa sp. & Drum stick & Moringaceae \\
\hline Phaseolus vulgaris & Kidney bean & Fabaceae \\
\hline Solanum melongena & Brinjal & Solanaceae \\
\hline Arachis hypogaea & Groundnut & Fabaceae \\
\hline Cocos nucifera & Coconut & Arecaceae \\
\hline Glycine $\max$ & Soybean & Fabaceae \\
\hline Ricinus communis & Castor & Euphorbiaceae \\
\hline Gossypium spp. & Cotton & Malvaceae \\
\hline Annona squamosa & Custard apple & Annonaceae \\
\hline Artocarpus heterophyllus & Jack fruit & Moraceae \\
\hline Carica papaya & Papaya & Caricaceae \\
\hline Citrus sinensis & Sweet lemon & Rutaceae \\
\hline Emblica officinalis & Indian gooseberry & Euphorbiaceae \\
\hline Ficus racemosa & Fig & Moraceae \\
\hline Mangifera indica & Mango & Anacardiaceae \\
\hline Manilkara zapota & Sapota & Sapotaceae \\
\hline Musa spp. & Banana & Musaceae \\
\hline
\end{tabular}




\begin{tabular}{|c|c|c|}
\hline Persea americana & Avacado & Lauraceae \\
\hline Psidium guajava & Guava & Myrtaceae \\
\hline Punica granatum & Pomegranate & Lythraceae \\
\hline Syzygium jambos & Rose apple & Myrtaceae \\
\hline Terminalia catappa & Almond & Combretaceae \\
\hline Vitis vinifera & Grapes & Vitaceae \\
\hline Dahlia sp. & Dahlia & Asteraceae \\
\hline Ficus elastica & Rubber tree & Moraceae \\
\hline Gerbera sp. & Gerbera & Asteraceae \\
\hline Gladiolus sp. & Gladiolus & Amaryllidaceae \\
\hline Hibiscus spp. & Hibiscus & Malvaceae \\
\hline Rose indica & Rose & Rosaceae \\
\hline Anacardium occidentale & Cashew & Anacardiaceae \\
\hline Areca catechu & Areca nut & Arecaceae \\
\hline Coffea arabica & Coffee & Rubiaceae \\
\hline Piper betel & Betel leaf plant & Piperaceae \\
\hline Jatropha sp. & Jatropha & Euphorbiaceae \\
\hline Cajanus cajan & Pigeon pea & Fabaceae \\
\hline Lantana camara & Lantana & Verbenaceae \\
\hline Phaseolus vulgaris & Beans & Fabaceae \\
\hline Sesbania grandiflora & Agathi & Fabaceae \\
\hline Azadirachta indica & Neem & Meliaceae \\
\hline Piper nigrum & Pepper & Piperaceae \\
\hline Santalum album & Sandal & Santalaceae \\
\hline Eucalyptus sp. & Eucalyptus & Myrtaceae \\
\hline
\end{tabular}

(Ramani et al., 2002; Hodges and Evans, 2007; Mani, 2010; Kumari, 2011)

Table.2 Parasitoids of Spiralling whitefly, Aleurodicus dispersus in India

\begin{tabular}{|l|c|l|}
\hline \multicolumn{1}{|c|}{ Parasitoids } & Family and Order & \multicolumn{1}{|c|}{ Reference } \\
\hline $\begin{array}{l}\text { Encarsia haitiensis } \\
\text { Dozier } \\
\text { (=Encarsia meritoria } \\
\text { Gahan) }\end{array}$ & $\begin{array}{c}\text { Aphelinidae } \\
\text { Hymenoptera }\end{array}$ & $\begin{array}{l}\text { Anon., (2000) Srinivasa } \text { et al. (1999); } \\
\text { Beevi } \text { et al. (1999); } \\
\text { Mani et al. (2001); Geetha and } \\
\text { Swamiappan, 2001b) }\end{array}$ \\
\hline $\begin{array}{l}\text { Encarsia } \\
\text { guadeloupae } \\
\text { Viggiani }\end{array}$ & $\begin{array}{l}\text { Aphelinidae } \\
\text { Leptus sp. }\end{array}$ & $\begin{array}{l}\text { Mani et al. (2001); Beevi and Lyla } \\
(2001)\end{array}$ \\
\hline
\end{tabular}


Table.3 Predators of Spiralling whitefly, Aleurodicus dispersus in India

\begin{tabular}{|c|c|c|}
\hline Predator & Family and Order & Reference \\
\hline Axinoscymnus puttarudiahi & $\begin{array}{l}\text { Coccinellidae, } \\
\text { Coleoptera }\end{array}$ & $\begin{array}{l}\text { Mani and Krishnamoorthy (1999a, c) } \\
\text { Mariam (1999); Muralikrishna (1999) }\end{array}$ \\
\hline Curinus coeruleus Muls. & $\begin{array}{l}\text { Coccinellidae, } \\
\text { Coleoptera }\end{array}$ & Mani et al. (2001) \\
\hline Horniolus sp. & $\begin{array}{l}\text { Coccinellidae, } \\
\text { Coleoptera }\end{array}$ & Anon., (2002) \\
\hline $\begin{array}{l}\text { Cheilomenes sexmaculata } \\
\text { (Fab.) }\end{array}$ & $\begin{array}{l}\text { Coccinellidae, } \\
\text { Coleoptera }\end{array}$ & $\begin{array}{l}\text { Palaniswami et al. (1995) } \\
\text { Mani and Krishnamoorthy (1999a) } \\
\text { Mariam (1999); Muralikrishna (1999) } \\
\text { Geetha (2000) }\end{array}$ \\
\hline $\begin{array}{l}\text { Cryptolaemus montrouzieri } \\
\text { Muls }\end{array}$ & $\begin{array}{l}\text { Coccinellidae, } \\
\text { Coleoptera }\end{array}$ & $\begin{array}{l}\text { Mani and Krishnamoorthy (1999a) } \\
\text { Muralikrishna (1999) } \\
\text { Geetha (2000) }\end{array}$ \\
\hline Chilocorus nigrita (Fab.) & $\begin{array}{l}\text { Coccinellidae, } \\
\text { Coleoptera }\end{array}$ & $\begin{array}{l}\text { Mani and Krishnamoorthy (1999b) } \\
\text { Geetha (2000) }\end{array}$ \\
\hline Anegleis cardoni (Wiese) & $\begin{array}{l}\text { Coccinellidae, } \\
\text { Coleoptera }\end{array}$ & $\begin{array}{l}\text { Mani } \text { et al. }(2001) \\
\text { Mariam (1999); } \\
\text { Geetha (2000) }\end{array}$ \\
\hline Anegleis perrotteti (Muls.) & $\begin{array}{l}\text { Coccinellidae, } \\
\text { Coleoptera }\end{array}$ & Anon. (2002) \\
\hline Jauravia dorsalis (Wise.) & $\begin{array}{l}\text { Coccinellidae, } \\
\text { Coleoptera }\end{array}$ & Anon. (2002) \\
\hline Jauravia pallidula Motseh & $\begin{array}{l}\text { Coccinellidae, } \\
\text { Coleoptera }\end{array}$ & Anon. (2002) \\
\hline Rodolia amabilis Kapur & $\begin{array}{l}\text { Coccinellidae, } \\
\text { Coleoptera }\end{array}$ & Anon. (2002) \\
\hline Rodoloia breviuscula Weise & $\begin{array}{l}\text { Coccinellidae, } \\
\text { Coleoptera }\end{array}$ & $\begin{array}{l}\text { Anon. (2002) } \\
\text { Geetha (2000) }\end{array}$ \\
\hline Rodolia fumida Mulsant & $\begin{array}{l}\text { Coccinellidae, } \\
\text { Coleoptera }\end{array}$ & Anon. (2002); Geetha (2000) \\
\hline Serangium parcesetosum Sic & $\begin{array}{l}\text { Coccinellidae, } \\
\text { Coleoptera }\end{array}$ & Mani et al. (2000a) \\
\hline Nephus regularis Sic & $\begin{array}{l}\text { Coccinellidae, } \\
\text { Coleoptera }\end{array}$ & Anon. (2001) \\
\hline Scymnus sp. & $\begin{array}{l}\text { Coccinellidae, } \\
\text { Coleoptera }\end{array}$ & Anon. (2000) \\
\hline Psedoscymnus sp. & $\begin{array}{l}\text { Coccinellidae, } \\
\text { Coleoptera }\end{array}$ & Anon. (2000) \\
\hline Keiscymnus sp. & $\begin{array}{l}\text { Coccinellidae, } \\
\text { Coleoptera }\end{array}$ & Anon. (2000) \\
\hline Scymnus coccivora Ayyar & $\begin{array}{l}\text { Coccinellidae, } \\
\text { Coleoptera }\end{array}$ & Anon. (2002) \\
\hline $\begin{array}{l}\text { Scymnus latemaculatus } \\
\text { Motsch. }\end{array}$ & $\begin{array}{l}\text { Coccinellidae, } \\
\text { Coleoptera }\end{array}$ & Anon. (2002); Geetha (2000) \\
\hline Scymnus posticalis Sic & $\begin{array}{l}\text { Coccinellidae, } \\
\text { Coleoptera }\end{array}$ & Anon. (2002) \\
\hline
\end{tabular}




\begin{tabular}{|c|c|c|}
\hline Scymnus saciformis Motsch. & $\begin{array}{l}\text { Coccinellidae, } \\
\text { Coleoptera }\end{array}$ & Anon. (2002) \\
\hline Scymnus nubilus Muls. & $\begin{array}{l}\text { Coccinellidae, } \\
\text { Coleoptera }\end{array}$ & Anon. (2000) \\
\hline $\begin{array}{l}\text { Pseudaspidimerus flaviceps } \\
\text { (Walk.) }\end{array}$ & $\begin{array}{l}\text { Coccinellidae, } \\
\text { Coleoptera }\end{array}$ & Anon. (2002) \\
\hline $\begin{array}{l}\text { Pseudaspidimerus trinotatus } \\
\text { (Walk.) }\end{array}$ & $\begin{array}{l}\text { Coccinellidae, } \\
\text { Coleoptera }\end{array}$ & Anon. (2001) \\
\hline Cybocephalus sp. & $\begin{array}{c}\text { Nitidulidae, } \\
\text { Coleoptera }\end{array}$ & $\begin{array}{l}\text { Mani and Krishnamoorthy (2001) } \\
\text { Muralikrishna (1999) } \\
\text { Geetha (2000) }\end{array}$ \\
\hline Mallada astur (Banks) & $\begin{array}{l}\text { Chrysopidae, } \\
\text { Neuroptera }\end{array}$ & $\begin{array}{l}\text { Mani and Krishnamoorthy (1999a) } \\
\text { Mariam (1999); } \\
\text { Geetha (2000) }\end{array}$ \\
\hline Apertochrysa sp. & $\begin{array}{l}\text { Chrysopidae, } \\
\text { Neuroptera }\end{array}$ & $\begin{array}{l}\text { Mani and Krishnamoorthy (1999a) } \\
\text { Geetha et al. (1999) }\end{array}$ \\
\hline Nobilinus sp. & $\begin{array}{l}\text { Chrysopidae, } \\
\text { Neuroptera }\end{array}$ & Mani and Krishnamoorthy (1999a) \\
\hline $\begin{array}{l}\text { Mallada boninensis } \\
\text { (Okomato) }\end{array}$ & $\begin{array}{l}\text { Chrysopidae, } \\
\text { Neuroptera }\end{array}$ & Mani and Krishnamoorthy (1999a) \\
\hline Chrsoperla carnea (Steph) & $\begin{array}{l}\text { Chrysopidae, } \\
\text { Neuroptera }\end{array}$ & Geetha et al. (2000) \\
\hline Symherobius barberi (Banks) & $\begin{array}{l}\text { Hemerobiidae, } \\
\text { Neuroptera }\end{array}$ & Paulson and Kumashiro (1985) \\
\hline Hemerobius sp. & $\begin{array}{l}\text { Hemerobiidae, } \\
\text { Neuroptera }\end{array}$ & Mani et al. (2001) \\
\hline $\begin{array}{l}\text { Notiobiella viridinervis } \\
\text { Banks }\end{array}$ & $\begin{array}{l}\text { Hemerobiidae, } \\
\text { Neuroptera }\end{array}$ & Mani et al. (2001) \\
\hline Leucopis sp. & $\begin{array}{l}\text { Chamaemyiidae, } \\
\text { Diptera }\end{array}$ & Anon. (2000) \\
\hline Triommato coccdivora (Felt) & $\begin{array}{l}\text { Cecidomiidae, } \\
\text { Diptera }\end{array}$ & Mani and Krishnamoorthy (1999a) \\
\hline Acletoxenus indicus Malloch & $\begin{array}{l}\text { Drosophilidae, } \\
\text { Diptera }\end{array}$ & Mani and Krishnamoorthy (1999a) \\
\hline Spalgis epeus (West wood) & $\begin{array}{l}\text { Lycaenidae, } \\
\text { Lepidoptera }\end{array}$ & Mani et al. (2001) \\
\hline Oecophylla smaragdina $(\mathrm{F})$ & $\begin{array}{l}\text { Formicidae, } \\
\text { Hymenoptera }\end{array}$ & Gopi et al. (2001a) \\
\hline Solenopsis geminata $(\mathbf{F})$ & $\begin{array}{l}\text { Formicidae, } \\
\text { Hymenoptera }\end{array}$ & Gopi et al. (2001a) \\
\hline Oxopes sp. & Oxypidae, Acari & Geetha (2000) \\
\hline $\begin{array}{l}\text { House sparrow, Passer } \\
\text { domesticus }(\mathrm{L})\end{array}$ & Aves & Gopi et al. (2001a) \\
\hline $\begin{array}{l}\text { Spiderhunter, Archnothera } \\
\text { longirostris (Latham) }\end{array}$ & Aves & Gopi et al. (2001a) \\
\hline $\begin{array}{l}\text { Pied bushchat, Saxicola } \\
\text { caprata (L) }\end{array}$ & Aves & Gopi et al. (2001a) \\
\hline $\begin{array}{l}\text { Tailor bird, Orthotomus } \\
\text { sutorius }\end{array}$ & Aves & Gopi et al. (2001a) \\
\hline
\end{tabular}


Table.4 Pathogens of spiralling whitefly, Aleurodicus dispersus in India

\begin{tabular}{|c|c|c|}
\hline Pathogen & Family and Order & Reference \\
\hline $\begin{array}{c}\text { Pacilomyces farinosus } \\
\text { (Brown and Smith) }\end{array}$ & Moniliales, Deutromycetes & Mani et al. $(2001)$ \\
\hline \begin{tabular}{c} 
Verticillium lecanii Zimm. \\
\hline
\end{tabular} & Moniliales, Deutromycetes & Mallappanavar (2000) \\
\hline
\end{tabular}

Heavy rains and cool temperatures may result in a temporary reduction of spiralling whitefly populations (Waterhouse and Norris, 1989). In countries where it has been introduced, chemical and biological control methods have been tried. This pest has been found susceptible to insecticides and neem oil in several countries (Wijesekera and Kudagamage, 1990; Wen et al., 1995; Alam et al., 1998). Tobacco extract, neem oil, fish oil, rosin soap and detergent solution with several insecticides have been found effective in India (Ranjith et al., 1996; Mariam, 1999; Muralikrishna, 1999; Geetha, 2000).

Spraying a dilute aqueous solution of detergent has been suggested to reduce infestations (Waterhouse and Norris, 1989). The use of light traps covered with Vaseline coating has been used to trap the adults (Srinivasan and Mohanasundaram, 1997). As A. dispersus is an exotic pest in most countries, classical biological control through the introduction of natural enemies from the area of origin of the pest is considered the best option for a sustainable solution (Lopez et al., 1997a).

\section{Cultural control}

Use of clean planting material delays the appearance of the whitefly population. Pruning the heavily infested trees and shrubs was recommended to minimize the spiralling whitefly incidence. After the pruning, the population rapidly increased within 4-5 months on guava (Geetha, 2000).

\section{Physical control}

The light trap was progressively suitable apparatus for monitoring the whitefly population. Use of light traps covered with Vaseline coating to rap adults have been suggested (Srinivasan and Mohanasundaram, 1997). Fluorescent light smeared with castor oil attracted and trapped a large number of adults (Mariam, 1999). Maximum adults were attracted and caught in yellow colour sticky trap (Geetha, 2000).

\section{Chemical control}

The whitefly can build up a resistance to most chemical pesticides and should not be treated with these. Spraying with chemicals also destroys natural enemies or biological control agents that have been released. Application of chemicals to the lower surface of infested leaves thoroughly reduces the whitefly abundance but temporarily. Muralikrishna in 1999 reported that Tobacco extract $(4 \%$,$) was$ found effective in minimising the spiralling whitefly. Spraying of neem oil (2\%), fish oil rosin soap (4\%) and detergent soap solution $(5 \%)$ reduces the whitefly population (Ranjith et al., 1996; Mariam, 1999 and Geetha, 2000). Contact insecticides like malathion and carbaryl at $0.10 \%$ were also found effective against young nymphs (Ragumoorthy and Kempraj, 1996). Dichlorvos $0.08 \%$ was found toxic to various stages of spiralling whitefly (Mariam, 1999). Triazophos $0.08 \%$ and phosalone $0.07 \%$ were equally effective against spiralling whitefly (Geetha, 2000; Mallapanavar, 2000). Application of neem oil $2 \%$ and neem seed kernel extract $3 \%$ were 
found to be effective in suppressing the nymphal and adult whitefly population (Kirubavathy et al., 1999). Triazophos at $0.03 \%$ was found to be highly effective against spiralling whitefly (Kambrekar and Awaknavar, 2004). According to Dubey and Sundararaj (2004), Chorpyriphos at $0.04 \%$ was found to effective against $A$. dispersus.

\section{Biological control}

As A. dispersus is an exotic pest in most countries, classical biological control is considered to be the best option for a sustainable solution (Lopez et al., 1997a). In Hawaii, several Pacific islands, the Maldives, Taiwan and Tenerife (Canary Islands), biological control has been attempted by introducing natural enemies (aphelinids and coccinellids) from the Caribbean region or from other areas where the parasitoids have been introduced earlier and substantial control has been achieved (Kumashiro et al., 1983; Waterhouse and Norris, 1989; Greathead and Greathead, 1992; Chien et al., 2000; Nijhof et al., 2000). The aphelinid parasitoids Encarsia haitiensis and Encarsia guadeloupae have given excellent control of spiralling whitefly in several countries Malaysia, Philippines, Benin, Togo, Ghana, Nigeria Guam, Taiwan, Australia, Hawaii and some other Pacific islands (Waterhouse and Norris, 1989; D'Almeida et al., 1998; Mani and Krishnamoorthy, 2002). The natural predator complex did not have any significant effect on the spiralling whitefly populations as witnessed in many countries. Inundative releases of Cryptolaemus motrouzieri and Mallada astur against $A$. dispersus had only in temporary reduction of the whiteflies during 1998-1999 in Karnataka (Mani et al., 2001). Verticillium lecanii (Zimm)@1.33 x $10^{7}$ and Verticel@ $9.5 \mathrm{~g} / \mathrm{l}$ were found to be most effective against spiralling whitefly 7,15 and 21 days after spraying (Mallappanavar, 2000).

\section{Natural enemies}

In addition to the accidentally introduced aphelinids, several indigenous natural enemies have expanded their host range to this invading pest in India (Palaniswami et al., 1995; Mani and Krishnamoorthy, 1999a, b; PDBC, 2000; Ramani, 2000; Mani and Krishnamoorthy, 2000; Mani et al., 2000a; PDBC, 2001; Geetha and Swamiappan, 2001a). As many as 62 natural enemies have been recorded attacking $A$. dispersus in Trinidad, Columbia, Hawaii, Guam, Indonesia, Sri Lanka, Malaysia, Benin, Togo, Ghana, Nigeria, Philippines, Florida, Fiji, Pohnpei, Costa Rica and India.

\section{Parasitoids}

Two aphelinid parasitoids have been accidentally introduced along with the host. In Minicoy islands, the whitefly nymphs were found parasitised by aphelinids, which were identified later as Encarsia haitiensis and E. guadeloupae (Ramani, 2000). In the mainland, Beevi et al., (1999) recorded Encarsia sp. for the first time in January 1998 which was closer to Encarsia meritoria Gahan on spiralling whitefly in Thrissur, Kerala. Srinivasa et al., (1999) reported a species of Encarsia, which was closely related to E. haitiensis and E. meritoria on spiralling whitefly in February in Bangalore. Geetha and Swamiappan (2001c) also recorded Encarsia sp., which was closer to $E$. meritoria on spiralling whitefly during December 1998 around Coimbatore. Encarsia species reported by Srinivasa et al., (1999), Beevi et al., (1999) and Geetha and Swamiappan (2001c) appeared to be Encarsia haitiensis, which is closely related to or possibly conspecific with, E. meritoria (D’Almeida et al., 1998). The exploratory survey carried out around Thrissur and Thiruvananthapuram during February 2000 in Kerala yielded a large number of Encarsia haitiensis (Mani et al., 2000a). 


\section{Predators}

More than 40 indigenous predators, mostly generalists and few host-specific species, have been recorded in India (Ramani et al., 2002). The major predators are neuropterans (chrysopids, hemerobiids and an unidentified coniopterygid), a new species of nititulid beetle, Cybocephalus sp. and several coccinellids. Many coccinellid predators and aphelinid parasitoids (Encarsia spp.) were found on whitefly species in Trinidad and some were utilized for classical biological control in Hawaii and other regions (Cock, 1985; Kumashiro et al., 1983). Lopez et al., (1997b) found three species of the coccinellid Nephaspis and several generalist predators including syrphids, chrysopids, spiders and ants preying on whitefly in Trinidad and Tobago. Cybocephalus sp. was recorded for the first time from Minicoy (Ramani, 2000) and later found commonly occurring in and around Bangalore, in association with the whitefly almost throughout the year, especially at high host densities (PDBC, 2000; Mani and Krishnamoorthy, 2000; PDBC, 2001). Cybocephalus spp. are known to be mainly predators of diaspine scales (Blumberg and Swirski, 1982), but some species like Cybocephalus aleyrodiphagus on Orchamoplatus citri (Takahashi) (Kirejtshuk et al., 1997) and this species have been recorded preying on whiteflies.

Out of the 26 species of coccinellids, the ones commonly found in the spiralling whitefly colonies are Anegleis cardoni (Weise), Anegleis perrotteti (Mulsant), Axinoscymnus puttarudriahi, Cheilomenes sexmaculata $(\mathrm{F})$, three species of Jauravia, Nephus regularis (Sicard), Pseudoscymnus sp., Pseudaspidimerus flaviceps (Walker) Pseudaspidimerus trinotatus (Thunberg), and Scymnus saciformis Motschulsky. Scymnus sp. was recorded as a common predator in Costa Rica (Metzler and Laprade, 1998).
Axinoscymnus sp. and C. sexmaculata have also been found in Indonesia (Kajita et al., 1991) and A. puttarudriahi was found feeding on the eggs of the whitefly in Sri Lanka (Wijesekera and Kudagamage, 1990).

Mani and Krishnamoorthy (1997) found that the naturalized Australian ladybird beetle, Cryptolaemus montrouzieri Mulsant preyed on the whitefly almost throughout the year, but had little effect in reducing the pest population. Mani and Krishnamoorthy (1999b) and Geetha and Swamiappan (2001c) have also studied the predatory potential and developmental period of $C$. montrouzieri on the whitefly in the laboratory. It was also recorded in Hawaii (Paulson and Kumashiro, 1985). Cryptolaemus montrouzieri mainly feeds on pseudococcids and may in all probability be an incidental record in mixed infestations of whiteflies and pseudococcids, especially those containing Ferrisia virgata (Cockerell). Curinus coeruleus (Mulsant) has been recorded feeding on $A$. dispersus in India (Mani et al., 2000a; PDBC, 2001) and also in Hawaii (Waterhouse and Norris, 1989) and the Philippines (Villacarlos and Robin, 1992). Several birds, ants and spiders have also been recorded feeding on A. dispersus in India (Gopi et al., 2001b).

\section{Pathogens}

The only pathogen recorded on A. dispersus has been Paecilomyces farinosus (Holm.) Brown and Smith from areas near Bangalore (Mani et al., 2000a; PDBC, 2001).

In conclusion the Aleurodicus dispersus is capable of spreading very fast from one location to another location. In the next few years, the spiralling whitefly may well be discovered in many more states in India. Available evidence suggests that new infestations have often resulted from transportations of infested plants. Chemical 
control is not practicable because of the abundance of host plants including some large size avenue trees and widespread distribution. With the accidental introduction of both species of Encarsia into India, a visible reduction in the population of $A$. dispersus has been noticed in Minicoy, Agatti and Kavaratti islands of Lakshadweep, Karnataka and Kerala, similar to that witnessed in Hawaii, Guam and other Pacific islands, West Africa and Tenerife. In south Asia, A. dispersus has been reported from Bangladesh, Sri Lanka and the Maldives in addition to India, but the two introduced aphelinid parasitoids have not been so far reported from Sri Lanka and Bangladesh. The impact of the accidental introductions of the parasitoids in conjunction with the indigenous natural enemies, on the whitefly populations, has to be carefully assessed in India, before any further introductions are considered.

\section{References}

Ahamed, C. A. A., Narayanaswamy, K. C., Ramegowda, T., Chandrakala, M. V. 1999. Impact of feeding spiralling whitefly affected mulberry leaf on nutritional parameters and cocoon conversion efficiency in the silkworm, Bombyx mori L. during fifth instar. Mysore Journal of Agricultural Sciences, 33: 355-360.

Aishwariya, K. K., Manjunatha, M., Naik, M. 2007a. Biology and host range of spiralling whitefly. Karnataka Journal of Agricultural Sciences, 20: 149-152.

Aishwariya, K. K., Manjunatha, M., Naik, M. 2007b. Seasonal incidence of spiralling whitefly Aleurodicus dispersus Russell and its natural enemies in relation to weather in Shimoga. Karnataka Journal of Agricultural Sciences, 20(1): 146-148.

Akinlosotu, T. A., Jackai, L. E. N., Ntonifor, N. N., Hassan, A. T., Agyakwa, C. W., Odebiyi, J. A., Akingbohungbe, A. E.,
Rossel, H. W. 1993. Spiralling whitefly Aleurodicus dispersus in Nigeria. FAO Plant Protection Bulletin, 41: 127-129.

Alam, S., Islam, M. N., Alam, M. Z., Islam, M. S. 1998. Effectiveness of three insecticides for the control of the spiralling whitefly, Aleurodicus dispersus Russell (Homoptera: Aleyrodidae), of guava. Bangladesh Journal of Entomology, 8: 53-58.

Anonymous. 1987. Study on control of the whitefly. Annual Report of the Megir Gumbek Research Branch, Department of Agriculture for the year 1986. Sarawak, Malaysia; Department of Agriculture, pp. 83-84.

Anonymous. 2000. Annual Report of Project Directorate of Biological Control for 1999-2000, PDBC, Bangalore, p.216.

Anonymous. 2001. Annual Report of Project Directorate of Biological Control for 2000-2001, PDBC, Bangalore, p. 202.

Anonymous. 2001. Annual Report of Project Directorate of Biological Control for 2000-2001, PDBC, Bangalore, p.202.

Anonymous. 2002. Annual Report of Project Directorate of Biological Control for 2001-2002, PDBC, Bangalore, p.221.

Beevi, S. P., Lyla, K. R. 2001. Host plantmediated natural parasitism by Encarsia spp. (Aphelinidae: Hymenoptera) on spiralling whitefly, Aleurodicus dispersus Russell (Aleyrodidae: Homoptera). In: Verghese, A., Parvatha Reddy, P. (eds) Proceedings, 2nd National Symposium on Integrated Pest Management in Horticultural Crops: New Molecules, Biopesticides and Environment, Bangalore, India; Association for Advancement of Pest Management in Horticultural Ecosystems, pp. 208-210.

Beevi, S. P., Lyla, K. R., Vidya, P. 1999. Report of Encarsia (Hymenoptera: Aphelinidae) on spiralling whitefly Aleurodicus dispersus Russell (Homoptera: Aleyrodidae), Insect 
Environment, 5: 44.

Blumberg, D., Swirski, E. 1982. Comparative biological studies on two species of predatory beetles of the genus Cybocephalus (Coleoptera: Cybocephalidae). Entomophaga, 27: 6776.

Carver, M., Reid, I. A. 1996. Aleyrodidae (Hemiptera: Sternorrhyncha) of Australia. Canberra, Australia; CSIRO Division of Entomology, Technical Paper No. 37,55 pp.

Chien, C. C., Chou, L. Y., Chang, S. C. 2000. Introduction, propagation and liberation of two parasitoids for the control of spiralling whitefly (Homoptera: Aleyrodidae) in Taiwan. Chinese Journal of Entomology, 20: 163-178.

Cock, M. J. W. 1985. A review of biological control of pests in the Commonwealth Caribbean and Bermuda up to 1982. Farnham Royal, UK; Commonwealth Agricultural Bureaux. Technical Communication of the Commonwealth Institute of Biological Control, 9: 149.

D'Almeida, Y. A., Lys, J. A., Neuenschwander, P., Ajuonu, O. 1998. Impact of two accidentally introduced Encarsia species (Hymenoptera: Aphelinidae) and other biotic and abiotic factors on the spiralling whitefly Aleurodicus dispersus (Russell) (Homoptera: Aleyrodidae), in Benin, West Africa. Biocontrol Science and Technology, 8: 163-173.

David, B. V., Regu, K. 1995. Aleurodicus dispersus Russell (Aleyrodidae: Homoptera), a whitefly pest new to India. Pestology, 19: 5-7.

Douressamy, S., Chandramohan, N., Sivaprakasam, N., Subramanian, A., Babu, P. C. S. 1997. Management of spiralling whitefly. Indian Silk, 36: 1516.

Dubey, A. K., Sundararaj, R. 2004. Evaluation of neem products against
Aleurodicus dispersus Russell (Aleyrodidae: Homoptera) on Bauhinia variegata and Michelia champaca. Indian Journal of Plant Protection, 32: 126-128.

Firman, I. D. 1982. Plant protection news. Noumea, New Caledonia; South Pacific Commission, Information Circular No. 90 , p. 8.

Gajendra Babu, B., David, P. M. M. 1999. New host plant records and host range of the spiralling whitefly, Aleurodicus dispersus Russell, (Hemiptera: Aleyrodidae). Madras Agricultural Journal, 86: 305- 313.

Geetha, B., 2000. Biology and management of spiralling whitefly Aleurodicus dispersus (Russell) (Homoptera: Aleurodidae). PhD. Thesis, Tamil Nadu Agric. Univ., Coimbatore (India).

Geetha, B., Loganathan, M., Swamiappan, M. 1998. Record of spiralling whitefly, Aleurodicus dispersus Russell on groundnut. Insect Environment, 4: 55.

Geetha, B., Swamiappan, M. 2001a. Host range and natural enemies of spiralling whitefly, Aleurodicus dispersus in Tamil Nadu. Paper presented in: Nation. Sem. Emerging Trends Pests and Diseases Mgmt. Coimbatore, October 2001. Tamil Nadu Agric. Univ. Coimbatore, India, pp. 11-13.

Geetha, B., Swamiappan, M. 2001b. Predatory potential and developmental period of green lacewings, Cybocephalus sp. And Cryptolaemus montrouzieri on the spiralling whitefly, Aleurodicus dispersus (Russell). Abstracts, National Seminar on Emerging Trends in Pests and Diseases and their Management, Coimbatore, India; Tamil Nadu Agricultural University, 75-76.

Gopi, D., Neelannavar, T. N., Thirumurthi, S. 2001a. Incidence of spiralling whitefly, Aleurodicus dispersus among tree species. Paper presented in: Nation. Sem. 
Emerging Trends Pests and Diseases Mgmt. Coimbatore, October 2001. Tamil Nadu Agric. Univ. Coimbatore, India, pp. 11-13.

Gopi, D., Neelannavar, T. N., Thirumurthi, S. 2001b. Incidence of spiralling whitefly, Aleurodicus dispersus among tree species. Abstracts, National Seminar on Emerging Trends in Pests and Diseases and their Management, Coimbatore, India; Tamil Nadu Agricultural University, 71-72.

Greathead, D. J., Greathead, A. H. 1992. Biological control of insect pests by insect parasitoids and predators: the BIOCAT database. Biocontrol News and Information, 13: 61-68.

Hemalatha, Shree, M. P. 2008. Analysis of the trend in infestation by sapsuckers in mulberry crop system. Indian Journal of Sericulture, 47(1): 130-132.

Hodges, G. S., Evans, G. A. 2007. Host plant list of the whiteflies (Aleyrodidae) of the world, USDA/Animal Plant Health Inspection Service (APHIS), Washington, USA, p. 290.

Jagadish, K. S., Narayanaswamy, K. C., Jayaramaiah, M., Naika, R., Govindan, R., Nagarajaiah, C. 2003. Seasonal incidence, host range and spatial distribution of spiralling whitefly, Aleurodicus dispersus infesting mulberry. Paper presented at Natl. Sem. Diseases and Pest Management in Sericulture, 1213, December, 2003, Seri. College, Chintamani, Abstract No. 20.

Kajita, H., Samudra, I. M., Naito, A. 1991. Discovery of the spiralling whitefly Aleurodicus dispersus Russell (Homoptera: Aleyrodidae) from Indonesia, with notes on its host plants and natural enemies. Applied Entomology and Zoology, 26: 397-400.

Kambrekar, D. N., Awaknavar, J. S. 2004. Field evaluation of insecticides and oil combinations against spiralling whitefly,
Aleurodicus dispersus on guava. Karnataka Journal of Agricultural Sciences, 17: 712-716.

Kirejtshuk, A. G., James, D. G., Heffer, R. 1997. Description and biology of a new species of Cybocephalus Erichson (Coleoptera: Nitidulidae), a predator of Australian citrus whitefly. Australian Journal of Entomology, 36: 81-86.

Kirubavathy, K., Saranya, Ninan, M. 1999. Neem for the management of whiteflies on tapioca. Paper presented In National Symposium on Biological Control Insecta in Agricultural Forestry, Medicine and Veterinary Science, Bharathiar University Coimbatore, India, 21-22.

Kumari, N. V. 2011. Spiralling Whitefly, Aleurodicus dispersus Russell: New major pest of mulberry. Indian Streams Research Journal, 1(4): 1-5.

Kumashiro, B. R., Lai, P. Y., Funasaki, G. Y., Teramoto, K. K. 1983. Efficacy of Nephaspis amnicola and Encarsia haitiensis in controlling Aleurodicus dispersus in Hawaii. Proceedings of the Hawaiian Entomological Society, 24: 261-269.

Lambkin, T. 1998. Spiralling whitefly threat to Australia. Brisbane, Queensland, Australia; Department of Primary Industry, Quarantine Bulletin No. 8.

Lopez, V. F., Kairo, M. T. K., Carl, K. P. 1997a. Dossier on Nephaspis bicolor Gordon (Coccinellidae: Scymninae), a potential biological control agent for the spiralling whitefly, Aleurodicus dispersus Russell (Aleyrodidae). Curepe, Trinidad and Tobago; International Institute of Biological Control, unpublished report, p.32.

Lopez, V. F., Kairo, M. T. K., Carl, K. P. 1997b. Strengthening of the biological control programme against the spiralling whitefly, Aleurodicus dispersus, in Togo. Curepe, Trinidad and Tobago; 
International Institute of Biological Control, unpublished technical report, p.70.

Mallappanavar, M. C. 2000. Bioecology and management of spiralling whitefly, Aleurodicus dispersus Russell by Verticillium lecanii (Zimm.). M.Sc. (Agri.) Thesis, University of Agricultural Sciences, Dharwad (India).

Mani, M. 2010. Origin, introduction, distribution and management of the invasive spiralling whitefly, Aleurodicus dispersus Russell in India. Karnataka Journal of Agricultural Sciences, 23(1): 59-75.

Mani, M., Dinesh, M. S., Krishnamoorthy, A. 2000a. Biological control studies on the spiralling whitefly, Aleurodicus dispersus Russell (Homoptera: Aleyrodidae). Abstracts, Entomocongress 2000Perspectives for the New Millennium, Trivandrum, India. Association for Advancement of Entomology, 37-38.

Mani, M., Dinesh, M. S., Krishnamoorthy, A. 2000b. Presence of Encarsia spp. on spiralling whitefly, Aleurodicus dispersus (Russell) in peninsular India. Insect Environment, 6: 100.

Mani, M., Dinesh, M. S., Krishnamoorthy, A. 2001. Biological control studies on the spiralling whitefly, Aleurodicus dispersus Russell. (Hemiptera, Aleyrodidae). Entomon, 26: 62-69.

Mani, M., Dinesh, M. S., Krishnamoorthy, A. 2003. Survey and evaluation of natural enemies of the exotic spiralling whitefly, Aleurodicus dispersus Russell on vegetables in peninsular India. Proceedings of International Conference on Vegetables, PNASF, Bangalore, India. pp. 315-318.

Mani, M., Krishnamoorthy, A. 1996. Spiralling whitefly and its natural enemies on guava in Karnataka, Insect Environment, 2: 12.

Mani, M., Krishnamoorthy, A. 1997.
Discovery of Australian ladybird beetle (Cryptolaemus montrouzieri) on spiralling whitefly (Aleurodicus dispersus) in India. Insect Environment, 3: 5-6.

Mani, M., Krishnamoorthy, A. 1999a. Natural enemies and host plants of spiralling whitefly Aleurodicus dispersus Russell (Homoptera: Aleyrodidae) in Bangalore, Karnataka. Entomon, 24: 75-80.

Mani, M., Krishnamoorthy, A. 1999b. Predatory potential and development of the Australian ladybird beetle, Cryptolaemus montrouzieri Muls. on the spiralling whitefly, Aleurodicus dispersus Russell. Entomon, 24: 173-176.

Mani, M., Krishnamoorthy, A. 1999c. Chilocorus nigrita on spiralling whitefly. Insect Environment, 4: 118-119.

Mani, M., Krishnamoorthy, A. 2000. Population dynamics of spiralling whitefly, Aleurodicus dispersus Russell (Aleyrodidae, Homoptera) and its natural enemies on guava in India. Entomon, 25: 29-34.

Mani, M., Krishnamoorthy, A. 2002. Classical biological control of spiralling whitefly, Aleurodicus dispersus RussellAn appraisal. Insect Science and Its Application, 22: 263-273.

Mariam, M. A. 1999. Biology and management of spiralling whitefly, Aleurodicus dispersus Russell (Homoptera: Aleyrodidae) on mulberry. M.Sc. (Ag) Thesis, Tamil Nadu Agricultural University, Coimbatore, $\mathrm{p}$. 88.

Mariam, M. A., Douressamy, S., Chandramohan, N. 2000. New hosts of spiralling whitefly (SWF) Aleurodicus dispersus Russell (Homoptera: Aleyrodidae). Insect Environment, 6: 70.

Martin, J. H. 1990. The whitefly species Aleurodicus dispersus and its rapid extension of range across the Pacific and South-East Asia. MAPPS Newsletter, 14: 
36-37.

M'Boob, S. S., van Oers, C. C. M. 1994. Spiralling whitefly (Aleurodicus dispersus): a new problem in Africa. FAO Plant Protection Bulletin, 42: 5962.

Metzler, B. H., Laprade, S. 1998. Natural enemies of the spiralling whitefly, Aleurodicus dispersus Russell (Homoptera: Aleyrodidae): parasitoids and predators. Agronomia Mesoamericana, 9: 41-44.

Muniappan, R. 1996. Spiralling whitefly threat. The Hindu, p.12.

Muralikrishna, M. 1999. Bioecology, host range and management of spiralling whitefly, Aleurodicus dispersus Russell (Homoptera: Aleyrodidae). M.Sc. (Agri.) Thesis, University of Agricultural Sciences, Bangalore (India).

Mware, B., Olubayo, F., Narla, R., Songa, J., Amata, R., Kyamanywa, S., Ateka, E. M. 2010. First record of spiralling whitefly in coastal Kenya: Emergence, host range, distribution and association with cassava brown streak virus disease. International Journal of Agriculture and Biology, 12: 411-415.

Nambiar, S. N. 1997. There is a winged threat to Bangalore's flora. The Times of India, p.1.

Narayanaswamy, K. C., Ramegowda, T. 1999. Incidence of spiralling whitefly on mulberry. Insect Environment, 5: 128129.

Narayanaswamy, K. C., Ramegowda, T., Raghuraman, R., Manjunath, M. S. 1999. Biochemical changes in spiralling whitefly (Aleurodicus dispersus Russell) infested mulberry leaf and their influence on some economic parameters of silkworm (Bombyx mori L.). Entomon, 24: 215-220.

Neuenschwander, P. 1994. Spiralling whitefly Aleurodicus dispersus, a recent invader and new cassava pest in Africa. African
Crop Science Journal, 2: 419-421.

Nijhof, B. W., Oudman, L., Torres, R., Garrido, C. 2000. The introduction of Encarsia guadeloupae (Hymenoptera, Aphelinidae) for control of Aleurodicus dispersus and Lecanoideus floccissimus (Homoptera, Aleyrodidae) on Tenerife. Proceedings of the Section Experimental and Applied Entomology of the Netherlands Entomological Society, 11: 41-47.

Palaniswami, M. S., Pillai, K. S., Nair, R. R., Mohandas, C. 1995. A new cassava pest in India, Cassava Newsletter, 19: 6-7.

Paulson, G. S., Kumashiro, B. R. 1985. Hawaiian Aleyrodidae. Proceedings of the Hawaiian Entomological Society 25: 103-129.

PDBC. 2000. Annual Report for 1999-2000. Bangalore, India; Project Directorate of Biological Control, p. 232.

PDBC. 2001. Annual Report for 2000-2001. Bangalore, India; Project Directorate of Biological Control, p. 218.

Prathapan, K. D. 1996. Outbreak of the spiralling whitefly, Aleurodicus dispersus Russell (Aleyrodidae, Homoptera) in Kerala. Insect Environment, 2: 36-37.

Ragumoorthy, K. N., Kempraj, T. 1996. Sucking pests of cassava. The Hindu, 119(123): 28.

Rajadurai, S., Thiagarajan, V. 2003. Mulberry sap-sucking pests. Indian Silk, 42(4): 5-8.

Ramani, S. 2000. Fortuitous introduction of an aphelinid parasitoid of the spiralling whitefly, Aleurodicus dispersus Russell (Homoptera: Aleyrodidae), into the Lakshadweep Islands with notes on host plants and other natural enemies. Journal of Biological Control, 14: 55-60.

Ramani, S., Bhumannavar, B. S. 2001. Spiralling whitefly, Aleurodicus dispersus in India and options for management of the pest. Paper presented at: National Seminar on Emerging Trends in Pest and Diseases Management. Tamil 
Nadu Agricultural University, Coimbatore, 11- 13.

Ramani, S., Poorani, J., Bhumannavar, B. S. 2002. Spiralling whitefly, Aleurodicus dispersus in India. Biocontrol News and Information, 23: 55-62.

Ranjith, A. M., Rao, D. S., Thomas, J. 1996. New host records of the mealy whitefly, Aleurodicus dispersus Russell in Kerala. Insect Environment, 2: 35.

Razak, T. A. 2002. Incidence of spiralling whitefly and leaf mealybug on coconut. Insect Environment, 8: 38-39.

Reddy, G. R. S., Chandarkar, P. S. 1999. First record of spiralling whitefly, Aleurodicus dispersus (Russell) on guava plants at Hyderabad. Plant Protection Bulletin (Faridabad), 51: 24.

Russell, L. M. 1965. A new species of Aleurodicus Douglas and two close relatives. The Florida Entomologist, 48: 47-55.

Sathe, T. V. 1999. Whitefly, Aleurodicus dispersus, a new pest of guava, Psidium guajava in Kolhapur, Maharashtra. Indian Journal of Entomology, 61: 195196.

Scanlan, F. M. 1995. Fruit production manual. Dhaka, Bangladesh; Development of Agricultural Extension, Bangladesh Agricultural Development Corporation, 116-117.

Sivaprakasam, N., Chandramohan, N. 1997. Spiralling whitefly on mulberry, The Hindu, p.28.

Srinivasa, M. V. 2000. Host plants of the spiralling whitefly, Aleurodicus dispersus (Hemiptera: Aleyrodidae), Pest Management in Horticultural Ecosystem, 6:79-105.
Srinivasa, M. V., Viraktamath, C. A., Reddy, C. 1999. A new parasitoid of the spiralling whitefly, Aleurodicus dispersus Russell (Hemiptera: Aleyrodidae) in South India. Pest Management in Horticultural Ecosystems, 5: 59-61.

Srinivasan, G., Mohanasundaram, M. 1997. A novel method to trap the spiralling whitefly, Aleurodicus dispersus Russell adults in the home gardens. Insect Environment, 3: 18.

Villacarlos, L. T., Robin, N. M. 1992. Biology and potential of Curinus coeruleus Mulsant, an introduced predator of Heteropsylla cubana Crawford. Philippine Entomologist, 8: 1247-1258.

Waterhouse, D. F., Norris, K. R. 1989. Aleurodicus dispersus Russell. In: Biological Control: Pacific Prospects Supplement 1, ACIAR Monograph No.12, ACIAR, Canberra, Australia, pp. 13-22.

Wen, H. C., Hsu, T. C., Chen, C. N. 1994. Supplementary description and host plants of the spiralling whitefly, Aleurodicus dispersus Russell. Chinese Journal of Entomology, 14: 147-161.

Wen, H. C., Tung, C. H., Chen, C. N. 1995. Yield loss and control of spiralling whitefly (Aleurodicus dispersus Russell). Journal of Agricultural Research of China, 44: 147-156.

Wijesekera, G. A. W., Kudagamage, C. 1990. Life history and control of spiralling whitefly Aleurodicus dispersus (Homoptera: Aleyrodidae): fastspreading pest in Sri Lanka. Quarterly Newsletter, Asia and Pacific Plant Protection Commission, 33: 22-24. 
How to cite this article:

Pradhan, P. P. and Abhilasa Kousik Borthakur. 2020. Menace of Spiralling Whitefly, Aleurodicus dispersus Russell on the Agrarian Community. Int.J.Curr.Microbiol.App.Sci. 9(12): 2756-2772. doi: https://doi.org/10.20546/ijcmas.2020.912.329 